\title{
Thirty Years of Experience with Intraductal Papillary Mucinous Neoplasm of the Pancreas: From Discovery to International Consensus
}

\author{
Masao Tanaka \\ Department of Surgery and Oncology, Graduate School of Medical Sciences, Kyushu University, Fukuoka, Japan
}

\author{
Key Words \\ Branch duct type $\cdot$ EUS · IPMN · Main duct type · Pancreatic \\ cancer
}

\begin{abstract}
Background: Intraductal papillary mucinous neoplasm (IPMN) of the pancreas is characterized by intraductal papillary proliferation of mucin-producing epithelial cells that exhibit various degrees of dysplasia. IPMN is classified as the main duct type (MD-IPMN) and the branch duct type (BDIPMN) according to the location of involvement, and into four histological subtypes (gastric, intestinal, pancreatobiliary, and oncocytic) according to the histomorphological and immunohistochemical characteristics. Mucin core protein expression correlates with the biological behavior and prognosis of the tumor. DNA analysis has shown that IPMN is associated with a number of gene mutations, but the roles of many of these mutations require further investigation. Most patients with MD-IPMN undergo tumor resection. Patients with BD-IPMN who do not undergo resection may develop malignant change, and concomitant separate pancreatic cancer occurs in 2-10\% of patients with IPMN. Patients with a strong family history may develop multiple BD-IPMNs as well as concomitant pancreatic cancer. Malignant changes are relatively easy to detect, especially by endoscopic ultrasonography (EUS), but the optimal surveillance protocol is currently unclear. Key Messages: The 2012 guidelines for the management of IPMN recommend that patients with
\end{abstract}

'high-risk stigmata' (obstructive jaundice, enhanced solid component, and main pancreatic duct size $\geq 10 \mathrm{~mm}$ ) should undergo resection. Patients with 'worrisome features' (cyst size $\geq 3 \mathrm{~cm}$, thickened enhanced cyst walls, non-enhanced mural nodules, main pancreatic duct size 5-9 mm, abrupt change in main pancreatic duct caliber with distal pancreatic atrophy, lymphadenopathy, and clinical acute pancreatitis) should be evaluated by EUS. EUS is a more sensitive test than computed tomography or magnetic resonance imaging for the early detection of malignancy. Conclusions: Most patients with MD-IPMN should undergo tumor resection. Patients with BD-IPMN who do not undergo resection should undergo careful surveillance including EUS for the early detection of malignant change and separate pancreatic cancer.

(c) 2015 S. Karger AG, Basel

\section{Introduction}

Intraductal papillary mucinous neoplasm (IPMN) of the pancreas was first reported by Ohhashi et al. [1] in 1980. One of their patients had invasive IPMN with profuse mucin secretion, which formed a fistula draining into the common bile duct. The same authors reported four patients with main duct type IPMN (MD-IPMN) that was successfully resected, resulting in a better prognosis than in ordinary type pancreatic ductal adenocarcinoma [2]. A large number of similar cases have subsequently been re-

\section{KARGER}

E-Mail karger@karger.com

www.karger.com/dig
(C) 2015 S. Karger AG, Basel

0012-2823/15/0904-0265\$39.50/0
Masao Tanaka, MD, PhD, FACS

Department of Surgery and Oncology, Graduate School of Medical Sciences Kyushu University

Fukuoka 812-8582 (Japan)

E-Mail masaotan@med.kyushu-u.ac.jp 
ported, and the definitions and nomenclature used to describe this tumor have been refined over time.

After a consensus meeting regarding the clinical management of IPMN at the biennial meeting of the International Association of Pancreatology (IAP) in Sendai, Japan in 2004, world experts issued international consensus guidelines for the management of IPMN and mucinous cystic neoplasm (MCN) of the pancreas in 2006 [3]. These guidelines greatly contributed to increased awareness and better understanding of these tumors, and facilitated further publication of numerous reports, especially regarding the clinical, radiological, histological, and genetic aspects of IPMN. The guidelines were revised in 2012 after the second consensus symposium during the IAP meeting in Fukuoka in 2010 [4]. This article reviews the evolution of the definitions and management of IPMN of the pancreas over the past 30 years. Readers may refer to a recent publication for more details [5].

\section{Definitions and Classification}

IPMN is characterized by intraductal papillary proliferation of mucin-producing epithelial cells. This tumor usually secretes excessive amounts of mucin, and was initially referred to as 'mucin-producing pancreatic tumor' in Japan. The epithelial cells exhibit a wide spectrum of dysplasia, from mild-, intermediate- and high-grade dysplasia to invasive carcinoma. The degree of epithelial dysplasia was formerly classified as adenoma, borderline tumor, or carcinoma; but the nomenclature was changed by the Fukuoka consensus guidelines, in accordance with the World Health Organization (WHO) classification [4, 6]. The former adenoma is now named mild or low-grade dysplasia, borderline tumor is now named moderate or intermediate-grade dysplasia, and carcinoma in situ is now severe or high-grade dysplasia [7]. At present, only invasive carcinoma derived from IPMN is considered malignant, and high-grade dysplasia is not considered malignant $[4,6]$. However, this has recently been questioned, as there have been some reported cases of highgrade dysplasia recurring as a distant metastasis after resection $[8,9]$. High-grade dysplasia is regarded as an indication for surgical resection as stated in the Fukuoka guidelines [4], although it is not clearly defined as malignant [6].

Profuse secretion of mucin by IPMN results in cystic dilatation of the pancreatic ducts (fig. 1). IPMN and similar lesions were previously referred to by a variety of names such as cystic adenocarcinoma [10], mucin-pro-

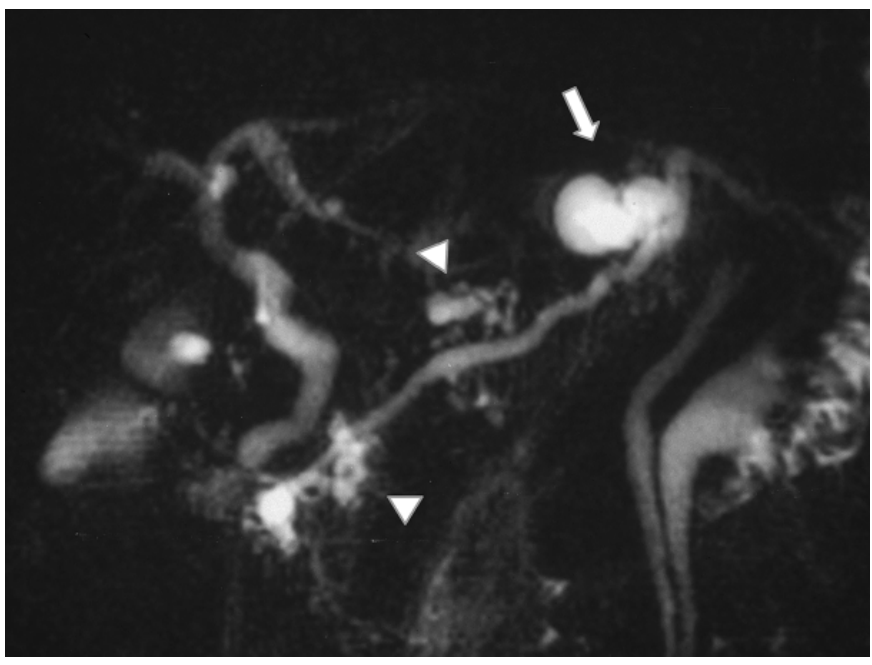

Fig. 1. Magnetic resonance cholangiopancreatography showing branch duct IPMNs. The largest lesion (arrow) is in the tail of the pancreas and the smaller lesions (arrowheads) are in the body of the pancreas.

ducing tumor [2], diffuse intraductal papillary adenocarcinoma [11], diffuse villous adenoma [12, 13], mucinous pancreatic duct ectasia [14], intraductal cystadenocarcinoma [15], intraductal mucin-hypersecreting neoplasm [16], mucinous ductal ectasia [17], papillary adenoma [18], intraductal mucin-producing tumor $[19,20]$, ductectatic type pancreatic ductal carcinoma [21], mucin-hypersecreting tumor [22], mucous-hypersecreting tumor [23], and intraductal papillary neoplasm [24]. Mucin-hypersecreting tumor was previously divided into the main duct type, the branch duct type, and the peripheral type according to the main location of the involvement. $\mathrm{Mu}$ cinous cystic neoplasm $(\mathrm{MCN})$ corresponds to the peripheral type, and IPMN corresponds to the main duct type and the branch duct type. The confusing terminology has now been improved by excluding the peripheral type from the classification of IPMN and clearly defining $\mathrm{MCN}$ as a separate entity.

The WHO [25] and Armed Forces Institute of Pathology [26] classifications clearly define IPMN and MCN as different entities. MCN is characterized by mucin-producing columnar epithelium supported by ovarian type stroma, and almost exclusively occurs in the body and tail of the pancreas in middle-aged women. In contrast, IPMN frequently occurs in the head of the pancreas in elderly men, and does not include ovarian type stroma. Histopathological examination is essential for differentiating between these two entities, but the clinical management is similar in many aspects [27]. 
Table 1. Consensus nomenclature and criteria for the classification of features of four histological subtypes of intraductal papillarymucinous neoplasm of the pancreas (cited from reference 30 with permission)

\begin{tabular}{|c|c|c|c|c|c|c|}
\hline Type & Mimicker & Criteria & Atypia & MUC1 & MUC2 & MUC5AC \\
\hline Gastric & $\begin{array}{l}\text { Gastric } \\
\text { foveolae }\end{array}$ & $\begin{array}{l}\text { Thick finger-like } \\
\text { papillae, eosinophilic }>\text { basophilic cytoplasm, } \\
\text { basally located nuclei. } \\
\text { This type may have abundant flat areas }\end{array}$ & Mild/low-grade & - & - & + \\
\hline Intestinal & $\begin{array}{l}\text { Intestinal } \\
\text { villous } \\
\text { neoplasm }\end{array}$ & $\begin{array}{l}\text { Villous papillae, basophilic > eosinophilic } \\
\text { cytoplasm, enlarged oval and hyperchromatic } \\
\text { nuclei with pseudostratification. } \\
\text { This type may show low papillae consisting } \\
\text { of cells with amphophilic cytoplasm }\end{array}$ & $\begin{array}{l}\text { Moderate or severe/ } \\
\text { high-grade }\end{array}$ & - & + & + \\
\hline Pancreatobiliary & $\begin{array}{l}\text { Cholangio- } \\
\text { papillary } \\
\text { neoplasm }\end{array}$ & $\begin{array}{l}\text { Thin branching complex papillae, moderate } \\
\text { amphophilic cytoplasm, enlarged } \\
\text { hyperchromatic nuclei }\end{array}$ & Severe/high-grade & + & - & + \\
\hline
\end{tabular}

In 1993, Osako et al. [28] reported that the mucin core protein expression of IPMN correlated with the biological behavior and prognosis of the tumor, and that MUC2 expression was associated with poorer clinical outcomes [29]. In 2005, Furukawa et al. [30] proposed the classification of IPMN into four histological subtypes (gastric, intestinal, pancreatobiliary, and oncocytic) based on the histomorphological features of papillary proliferation and the immunohistochemical characteristics of mucin glycoproteins (table 1). Gastric type IPMN has finger-like papillary growths that are positive for MUC5AC but not for MUC1 or MUC2, intestinal type IPMN has villous papillae that characteristically express MUC2 and MUC5AC but not MUC1, pancreatobiliary type IPMN has an intricate thin arborizing papillary structure that is consistently positive for MUC5AC and focally positive for MUC1 but not MUC2, and oncocytic type IPMN has complicated thick papillae consisting of eosinophilic oncocytic cells that are consistently positive for MUC5AC and focally positive for MUC1 and/or MUC2.

During the last decade, the histological subtype has been demonstrated to have clinical significance in terms of predicting the biological behavior and prognosis of IPMN [31-34]. Invasive carcinoma derived from the non-intestinal type IPMN is associated with a poor prognosis, characterized by lymphatic invasion and a tubular invasive pattern [31], whereas invasive carcinoma derived from intestinal type IPMN is of the colloid type and is often minimally invasive [33]. It has been reported that the tumor stage is the most significant predictor of survival, followed by the histological subtype, which was a significant predictor in a subcohort of patients with invasive IPMN $[32,34]$.

\section{Clinical Management}

The treatment of MD-IPMN has not changed much over the past three decades. Most patients with MD-IPMN who are fit for surgery undergo tumor resection. However, the surgical indications for branch duct type IPMN (BD-IPMN) have become considerably more conservative over time.

The Sendai guidelines published in 2006 proposed a variety of strategies for the management of IPMN [3]. The guidelines recommended resection of most $\mathrm{BD}$ IPMN measuring $>3 \mathrm{~cm}$ in diameter even without mural nodules, and many patients with these tumors therefore underwent resection. As malignancy was found in 25.5\% of all BD-IPMNs resected and invasive cancer was found in $17.7 \%$, the Fukuoka guidelines included more conservative criteria for the surgical resection of BD-IPMN [4].

One of the remarkable characteristics of the Fukuoka guidelines was the adoption of two layers of criteria for assessment of IPMN: 'high-risk stigmata' considered to be indicative of malignancy, and 'worrisome features' possi- 
bly pointing toward malignancy. The high-risk stigmata include obstructive jaundice, enhanced solid component, and main pancreatic duct size $\geq 10 \mathrm{~mm}$, and patients with these features should undergo resection without delay. The worrisome features include a cyst size of $\geq 3 \mathrm{~cm}$, thickened and enhanced cyst walls, nonenhanced mural nodules, main pancreatic duct size 5-9 $\mathrm{mm}$, an abrupt change in the main pancreatic duct caliber with distal pancreatic atrophy, and lymphadenopathy on imaging examinations; and clinical acute pancreatitis. Patients with these features should be evaluated by endoscopic ultrasonography (EUS) for further risk stratification. Use of these two layers of criteria seems to result in more accurate assessment of the need for surgical treatment of BD-IPMN. EUS can demonstrate morphological features suggestive of malignancy such as mural nodules, irregularity and/or thickening of septa between cysts, and the presence of vascularity in these structures, and has gained an increasing role in the diagnosis of IPMN over the past decade [35]. Future surveillance of BD-IPMN will become increasingly reliant on the ability of EUS to detect malignant changes in IPMN.

\section{Molecular and Genetic Investigations}

In addition to the immunohistochemical mucin staining discussed earlier, genetic analysis of IPMN has progressed over recent years. DNA analysis by flow cytometry showed that IPMN tumor cells of intermediate-grade dysplasia were diploid, whereas those of high-grade dysplasia were aneuploid [36]. Two of five malignant MCNs were reported to be $\mathrm{p} 53$ positive, but there was no DNA aneuploidy in any of the 10 patients with IPMN (4 with low-grade dysplasia, 1 with intermediate-grade dysplasia, and 5 with high-grade dysplasia) [37].

The incidence of point mutations at codon 12 of the KRAS gene in IPMN has been studied [7, 38-43] extensively. Although KRAS point mutations are found in areas of low-grade as well as high-grade dysplasia, the frequency of the mutation generally increases with an increased degree of dysplasia. KRAS mutations were detected in the pancreatic juice of patients with IPMN, but also in the pancreatic juice of patients with chronic pancreatitis, and this is not a useful method of differentiating between carcinoma and adenoma [42]. A more recent study identified activating GNAS mutations at codon 201 as a highly specific genetic alteration in IPMNs $[44,45]$. BRAF mutations also contribute to the oncogenesis of IPMN/IPM carcinoma (IPMC), but at a lower frequency than KRAS mutations [46]. More recently, whole- exome sequencing revealed somatic mutations in KCNF1, DYNC1H1, PGCP, STAB1, PTPRM, PRPF8, RNASE3, SPHKAP, MLXIPL, VPS13C, PRCC, GNAS, KRAS, RBM10, RNF43, DOCK2, and CENPF genes in IPMN (table 2) $[47,48]$. The same study found that $48(40.7 \%)$ of 118 IPMNs, but none of 32 pancreatic ductal adenocarcinomas, harbored GNAS mutations. G-protein alpha-subunit is encoded by GNAS and its downstream targets, phosphorylated substrates of protein kinase $A$, and its expression in IPMN was found to be associated with the histological grade of IPMN. GNAS mutations are unique to IPMN, and activation of G-protein signaling may play a crucial role in IPMN progression. Amato et al. [49] reported an even higher frequency of GNAS mutation in IPMN $(38 / 48 ; 79 \%)$ using next-generation sequencing. The second most common mutation was $K R A S$, found in $50 \%$ of IPMN, and the third most common was RNF43, found in 14\%. GNAS and/or KRAS mutations were found in $92 \%$ of IPMNs. TP53 and BRAF mutations were observed only in high-grade IPMN (10 and $6 \%$, respectively).

In the latter half of the last three decades, investigation had focused on the molecular and genetic analysis of IPMN. The significance of GNAS mutations is relatively well understood, but the roles of other genetic mutations require further investigation.

\section{Invasive Pancreatic Cancer Concomitant with IPMN}

In the past two decades, the occurrence of coexistent but separate pancreatic cancer in patients with IPMN has been of particular interest. Tanaka et al. [50] first reported noninvasive pancreatic cancer concomitant with BDIPMN in 1997. It has been proposed that the presence of BD-IPMN may be an indicator of noninvasive pancreatic cancer [51]. The same authors reported 76 patients who underwent resection of BD-IPMN, of which 7 (9.2\%) had concomitant noninvasive or invasive pancreatic cancer [52]. Subsequent reports of cases [53, 54] and many series from Japan [55-62] indicate that concomitant pancreatic cancer occurs in $2-10 \%$ of patients with IPMN [63]. Even a small ( $\leq 1 \mathrm{~cm}$ diameter) BD-IPMN is associated with an $8 \%$ risk of developing distinct pancreatic cancer during surveillance [56]. The reported yearly incidence of distinct pancreatic cancer in patients with BD-IPMN is $0.41-1.10 \%[56,58,62]$.

Although the malignant changes of BD-IPMN are relatively easy to detect, especially by EUS [35], and the surgical indications for BD-IPMN even with mural nodules 
Table 2. Mutations identified in IPMN by whole-exome sequencing (cited with modification from reference 47 with permission)

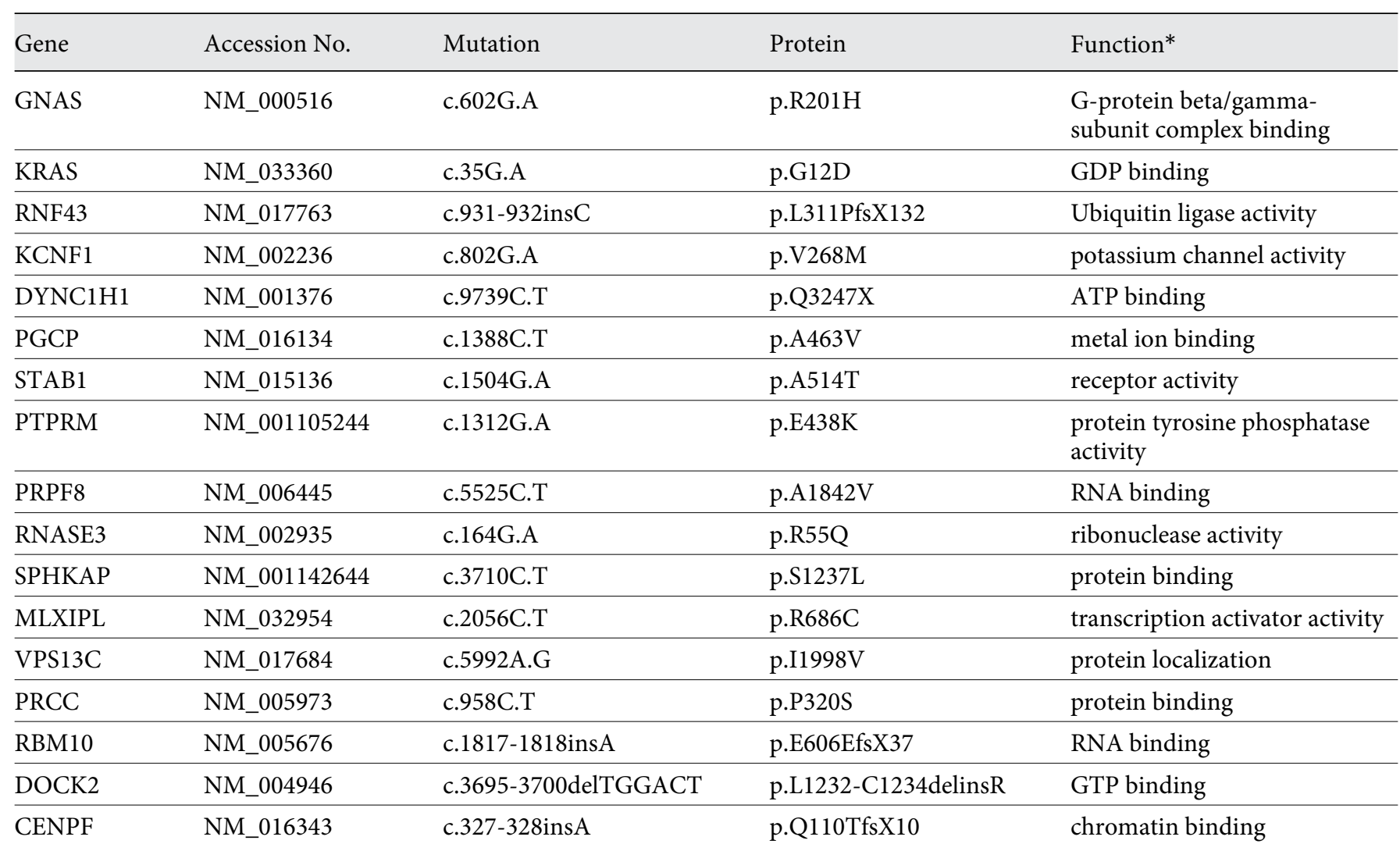

* Gene Ontology (http://www.ebi.ac.uk/GOA/).

G-protein = The guanine nucleotide-binding protein; IPMN = intraductal papillary mucinous neoplasm.

is becoming more conservative [64], effective surveillance strategies for the timely detection of concomitant pancreatic cancer in patients with IPMN are urgently needed. It is currently debated whether the imaging surveillance interval proposed for patients with IPMN by the Fukuoka guidelines is adequate, because even 6-monthly surveillance may miss the diagnosis of pancreatic cancer at a sufficiently early stage [65]. Kamata et al. [66] surveyed 102 patients with apparently benign BD-IPMN by 6-monthly EUS and other imaging examinations. They found distinct pancreatic cancer in 7 patients (7\%), but no cases of malignant transformation of BD-IPMN. Interestingly, a combination of computed tomography and magnetic resonance imaging performed immediately after the detection of pancreatic cancer by EUS showed the lesion in only $43 \%$ of cases, indicating the pivotal role of EUS in the early detection of pancreatic cancer.

Some studies have investigated the characteristics of IPMN associated with distinct pancreatic cancer. Ideno et al. [67] investigated the histological subtype of IPMN in patients with concomitant pancreatic cancer, and found a high frequency of gastric subtype. Concomitant pancreatic cancer may occur in patients with MD-IPMN as well as BD-IPMN [8]. Furthermore, distinct pancreatic cancer may develop even after the resection of IPMN. Ohtsuka et al. [68] reported that 17 (9.9\%) of 172 patients who underwent resection of IPMN subsequently developed distinct pancreatic cancer. Noninvasive concomitant cancer can be detected early in patients with IPMN by cytological examination of pancreatic juice collected during ERCP or pancreatic resection $[69,70]$.

Familial pancreatic cancer has been extensively studied in select institutions, to explore the genetic, environmental, and lifestyle factors associated with its pathogenesis [71]. Patients with a strong family history of pancreatic cancer may develop multiple BD-IPMNs as well as pancreatic cancer during surveillance, and the presence of BD-IPMN may be a sign of concomitant high-grade 
dysplasia, which was previously named pancreatic carcinoma in situ [72-74]. The Fukuoka guidelines recommend that the threshold for total pancreatectomy should be lowered in such patients, but there are currently insufficient data available to support this strategy.

\section{Disclosure Statement}

The author discloses no sponsorship, conflict of interest, or funding arrangements related to this review manuscript.

\section{References}

1 Ohashi K, Tajiri H, Gondo M, Yokoyama Y, Maruyama M, Takekoshi T, Matsuura Y, Kasumi F, Takagi K, Kato Y: A case of cystadenocarcinoma of the pancreas forming bilio-pancreatic fistula. Prog Dig Endosc 1980;17:261264.

2 Ohhashi K, Murakami F, Maruyama M, Takekoshi T, Ohta H, Ohhashi I, Takagi K, Kato Y: Four cases of mucous secreting pancreatic cancer. Prog Dig Endosc 1982;20:348-351.

-3 Tanaka M, Chari S, Adsay V, Fernandez-del Castillo C, Falconi M, Shimizu M, Yamaguchi K, Yamao K, Matsuno S; International Association of Pancreatology: International consensus guidelines for management of intraductal papillary mucinous neoplasms and mucinous cystic neoplasms of the pancreas. Pancreatology 2006;6:17-32.

-4 Tanaka M, Fernández-del Castillo C, Adsay V, Chari S, Falconi M, Jang JY, Kimura W, Levy P, Pitman MB, Schmidt CM, Shimizu M, Wolfgang CL, Yamaguchi K, Yamao K; International Association of Pancreatology: International consensus guidelines 2012 for the management of IPMN and MCN of the pancreas. Pancreatology 2012;12:183-197.

5 Tanaka M: Intraductal Papillary Mucinous Neoplasm, ed 1. Tokyo, Springer, 2014.

6 Adsay NV, Fukushima N, Furukawa T, Hruban RH, Klimstra DS, Kloppel G, Offerhaus GJA, Pitman MB, Shimizu M, Zamboni G: Intraductal neoplasm of the pancreas; in Bosman FT, Carneiro F, Hruban RH, Theise ND (eds): WHO classification of tumors of digestive system. Lyon, WHO Press, 2010, pp 304-313.

7 Sessa F, Solcia E, Capella C, Bonato M, Scarpa A, Zamboni G, Pellegata NS, Ranzani GN, Rickaert F, Klöppel G: Intraductal papillarymucinous tumours represent a distinct group of pancreatic neoplasms: an investigation of tumour cell differentiation and K-ras, p53 and c-erbB-2 abnormalities in 26 patients. Virchows Arch 1994;425:357-367.

8 Tamura K, Ohtsuka T, Ideno N, Aso T, Shindo K, Aishima S, Ohuchida K, Takahata S, Ushijima Y, Ito T, Oda Y, Mizumoto K, Tanaka M: Treatment strategy for main duct intraductal papillary mucinous neoplasms of the pancreas based on the assessment of recurrence in the remnant pancreas after resection: a retrospective review. Ann Surg 2014;259:360-368.

>9 Ohtsuka T, Matsunaga T, Kimura H, Watanabe Y, Tamura K, Ideno N, Aso T, Miyasaka Y, Ueda J, Takahata $\mathrm{S}$, Osoegawa $\mathrm{T}$, Igarashi $\mathrm{H}$, Ito $\mathrm{T}$, Ushijima Y, Ookubo F, Oda Y, Mizumoto K,
Tanaka M: Role of pancreatic juice cytology in the preoperative management of intraductal papillary mucinous neoplasm of the pancreas in the era of international consensus guidelines 2012. World J Surg 2014;38:2994-3001.

10 Ito Y, Blackstone MO, Frank PH, Skinner DB: Mucinous biliary obstruction associated with a cystic adenocarcinoma of the pancreas. Gastroenterology 1977;73:1410-1412.

11 Conley CR, Scheithauer BW, Weiland LH, van Heerden JA: Diffuse intraductal papillary adenocarcinoma of the pancreas. Ann Surg 1987;205:246-249.

12 Rogers PN, Seywright MM, Murray WR: Diffuse villous adenoma of the pancreatic duct. Pancreas 1987;2:727-730.

13 Payan MJ, Xerri L, Moncada K, Bastid C, Agostini S, Sastre B, Sahel J, Choux R: Villous adenoma of the main pancreatic duct: a potentially malignant tumor? Am J Gastroenterol 1990;85:459-463.

14 Agostini S, Choux R, Payan MJ, Sastre B, Sahel J, Clement JP: Mucinous pancreatic duct ectasia in the body of the pancreas. Radiology 1989;170:815-816.

15 Köhler B, Köhler G, Riemann J: Pancreoscopic diagnosis of intraductal cystadenoma of the pancreas. Dig Dis Sci 1990;35:382-384.

16 Rickaert F, Cremer M, Deveire J, Tavares L, Lambilliotte JP, Schröder S, Wurbs D, Klöppel G: Intraductal mucin-hypersecreting neoplasms of the pancreas. A clinicopathologic study of eight patients. Gastroenterology 1991;101:512-519.

17 Bastid C, Bernard JP, Sarles H, Payan MJ, Sahel J: Mucinous ductal ectasia of the pancreas: a premalignant disease and a cause of obstructive pancreatitis. Pancreas 1991;6:15-22.

18 Obara T, Saitoh Y, Maguchi H, Ura H, Yokota K, Okamura K, Namiki M: Papillary adenoma of the pancreas with excessive mucin secretion. Pancreas 1992;7:114-117.

19 Kawarada Y, Yano T, Yamamoto T, Yokoi H, Imai $\mathrm{T}$, Ogura $\mathrm{Y}$, Mizumoto R: Intraductal mucin-producing tumors of the pancreas. Am J Gastroenterol 1992;87:634-638.

20 Yamada M, Kozuka S, Yamao K, Nakazawa S, Naitoh Y, Tsukamoto Y: Mucin-producing tumor of the pancreas. Cancer 1991;68:159-168.

21 Furuta K, Watanabe H, Ikeda S: Differences between solid and duct-ectatic types of pancreatic ductal carcinomas. Cancer 1992;69: 1327-1333.

22 Yamaguchi K, Tanaka M: Mucin-hypersecreting tumor of the pancreas with mucin ex- trusion through an enlarged papilla. Am J Gastroenterol 1991;86:835-839.

23 Furukawa T, Takahashi T, Kobari M, Matsuno S: The mucus-hypersecreting tumor of the pancreas. Development and extension visualized by three-dimensional computerized mapping. Cancer 1992;70:1505-1513.

24 Yamaguchi K, Chijiiwa K, Shimizu S, Yokohata K, et al: Intraductal papillary neoplasm of the pancreas: a clinical review of 13 benign and four malignant tumours. Eur J Surg 1999; 165:223-229.

25 Klöppel G, Solcia E, Longnecker DS, Capella C, Sobin LH; World Health Organization: International histological classification of tumours. Histological typing of tumours of the exocrine pancreas, ed 2. Berlin, Springer-Verlag, 1996, pp 1-61.

26 Solcia E, Capella C, Klöppel G: Tumors of the pancreas; in Rosai J, Sorbin L (eds): Atlas of Tumor Pathology, fascicle 20, 3rd series. Washington, DC, Armed Forces Institute of Pathology, 1997, pp 1-262.

27 Loftus EV Jr, Olivares-Pakzad BA, Batts KP, Adkins MC, Stephens DH, Sarr MG, DiMagno EP: Intraductal papillary-mucinous tumors of the pancreas: clinicopathologic features, outcome, and nomenclature. Gastroenterology 1996;110:1909-1918.

28 Osako M, Yonezawa S, Siddiki B, Huang J, Ho JJ, Kim YS, Sato E: Immunohistochemical study of mucin carbohydrates and core proteins in human pancreatic tumors. Cancer 1993;71:2191-2199.

29 Nakamura A, Horinouchi M, Goto M, Nagata K, Sakoda K, Takao S, Imai K, Kim YS, Sato E, Yonezawa S: New classification of pancreatic intraductal papillary-mucinous tumour by mucin expression: its relationship with potential for malignancy. J Pathol 2002;197:201-210.

-30 Furukawa T, Klöppel G, Volkan Adsay N, Albores-Saavedra J, Fukushima N, Horii A, Hruban RH, Kato Y, Klimstra DS, Longnecker DS, Lüttges J, Offerhaus GJ, Shimizu M, Sunamura M, Suriawinata A, Takaori K, Yonezawa S: Classification of types of intraductal papillarymucinous neoplasm of the pancreas: a consensus study. Virchows Arch 2005;447:794-799.

- 31 Sadakari Y, Ohuchida K, Nakata K, Ohtsuka T, Aishima S, Takahata S, Nakamura M, Mizumoto $\mathrm{K}$, Tanaka M: Invasive carcinoma derived from the nonintestinal type intraductal papillary mucinous neoplasm of the pancreas has a poorer prognosis than that derived from the intestinal type. Surgery 2010;147:812-817. 
32 Furukawa T, Hatori T, Fujita I, Yamamoto M, Kobayashi M, Ohike N, Morohoshi T, Egawa S, Unno M, Takao S, Osako M, Yonezawa S, Mino-Kenudson M, Lauwers GY, Yamaguchi H, Ban S, Shimizu M: Prognostic relevance of morphological types of intraductal papillary mucinous neoplasms of the pancreas. Gut 2011;60:509-516

-33 Nakata K, Ohuchida K, Aishima S, Sadakari Y, Kayashima T, Miyasaka Y, Nagai E, Mizumoto K, Tanaka M, Tsuneyoshi M, Oda Y: Invasive carcinoma derived from intestinal-type intraductal papillary mucinous neoplasm is associated with minimal invasion, colloid carcinoma, and less invasive behavior, leading to a better prognosis. Pancreas 2011;40:581-587.

-34 Mino-Kenudson M, Fernández-del Castillo C, Baba Y, Valsangkar NP, Liss AS, Hsu M, Correa-Gallego C, Ingkakul T, Perez Johnston R, Turner BG, Androutsopoulos V, Deshpande V, McGrath D, Sahani DV, Brugge WR, Ogino S, Pitman MB, Warshaw AL, Thayer SP: Prognosis of invasive intraductal papillary mucinous neoplasm depends on histological and precursor epithelial subtypes. Gut 2011;60:1712-1720.

- 35 Ohno E, Hirooka Y, Itoh A, Ishigami M, Katano Y, Ohmiya N, Niwa Y, Goto H: Intraductal papillary mucinous neoplasms of the pancreas: differentiation of malignant and benign tumors by endoscopic ultrasound findings of mural nodules. Ann Surg 2009;249: 628-634.

-36 Nishihara K, Fukuda T, Tsuneyoshi M, Kominami T, Maeda S, Saku M: Intraductal papillary neoplasm of the pancreas. Cancer 1993; 72:689-696.

- 37 Fléjou JF, Boulange B, Bernades P, Belghiti J, Hénin D: p53 protein expression and DNA ploidy in cystic tumors of the pancreas. Pancreas 1996;13:247-252.

38 Yanagisawa A, Kato Y, Ohtake K, Kitagawa T, Ohashi K, Hori M, Takagi K, Sugano H: c-Kiras point mutations in ductectatic-type mucinous cystic neoplasms of the pancreas. Jpn J Cancer Res 1991;82:1057-1060.

-39 Tada M, Omata M, Ohto M: Ras gene mutations in intraductal papillary neoplasms of the pancreas. Analysis in five cases. Cancer 1991; 67:634-637.

40 Lemoine NR, Jain S, Hughes CM, Staddon SL, Maillet B, Hall PA, Klöppel G: Ki-ras oncogene activation in preinvasive pancreatic cancer. Gastroenterology 1992;102:230-236.

-41 Satoh K, Sawai T, Shimosegawa T, Koizumi M, Yamazaki T, Mochizuki F, Toyota T: The point mutation of c-Ki-ras at codon 12 in carcinoma of the pancreatic head region and in intraductal mucin-hypersecreting neoplasm of the pancreas. Int J Pancreatol 1993;14:135143.

42 Kondo H, Sugano K, Fukayama N, Hosokawa K, Ohkura H, Ohtsu A, Mukai K, Yoshida S: Detection of K-ras gene mutations at codon 12 in the pancreatic juice of patients with intraductal papillary mucinous tumors of the pancreas. Cancer 1997;79:900-905.
43 Hong SM, Vincent A, Kanda M, Leclerc J, Omura N, Borges M, Klein AP, Canto MI, Hruban RH, Goggins M: Genome-wide somatic copy number alterations in low-grade PanINs and IPMNs from individuals with a family history of pancreatic cancer. Clin Cancer Res 2012;18:4303-4312.

-44 Wu J, Matthaei H, Maitra A, Dal Molin M, Wood LD, Eshleman JR, Goggins M, Canto MI, Schulick RD, Edil BH, Wolfgang CL, Klein AP, Diaz LA Jr, Allen PJ, Schmidt CM, Kinzler KW, Papadopoulos N, Hruban RH, Vogelstein B: Recurrent GNAS mutations define an unexpected pathway for pancreatic cyst development. Sci Transl Med 2011;3: 92ra66.

45 Dal Molin M, Matthaei H, Wu J, Blackford A, Debeljak M, Rezaee N, Wolfgang CL, Butturini G, Salvia R, Bassi C, Goggins MG, Kinzler KW, Vogelstein B, Eshleman JR, Hruban RH, Maitra A: Clinicopathological correlates of activating GNAS mutations in intraductal papillary mucinous neoplasm (IPMN) of the pancreas. Ann Surg Oncol 2013;20:38023808.

46 Schönleben F, Qiu W, Bruckman KC, Ciau NT, Li X, Lauerman MH, Frucht H, Chabot JA, Allendorf JD, Remotti HE, Su GH: BRAF and KRAS gene mutations in intraductal papillary mucinous neoplasm/carcinoma (IPMN/ IPMC) of the pancreas. Cancer Lett 2007;249: 242-248.

47 Furukawa T, Kuboki Y, Tanji E, Yoshida S, Hatori T, Yamamoto M, Shibata N, Shimizu K, Kamatani N, Shiratori K: Whole-exome sequencing uncovers frequent GNAS mutations in intraductal papillary mucinous neoplasms of the pancreas. Sci Rep 2011;1:161.

$48 \mathrm{Wu}$ J, Jiao Y, Dal Molin M, Maitra A, de Wilde RF, Wood LD, Eshleman JR, Goggins MG, Wolfgang CL, Canto MI, Schulick RD, Edil BH, Choti MA, Adsay V, Klimstra DS, Offerhaus GJ, Klein AP, Kopelovich L, Carter H, Karchin R, Allen PJ, Schmidt CM, Naito Y, Diaz LA Jr, Kinzler KW, Papadopoulos N, Hruban RH, Vogelstein B: Whole-exome sequencing of neoplastic cysts of the pancreas reveals recurrent mutations in components of ubiquitin-dependent pathways. Proc Natl Acad Sci U S A 2011;108:21188-21193.

49 Amato E, Molin MD, Mafficini A, Yu J, Malleo G, Rusev B, Fassan M, Antonello D, Sadakari Y, Castelli P, Zamboni G, Maitra A, Salvia R, Hruban RH, Bassi C, Capelli P, Lawlor RT, Goggins M, Scarpa A: Targeted next-generation sequencing of cancer genes dissects the molecular profiles of intraductal papillary neoplasms of the pancreas. J Pathol 2014;233: 217-227.

50 Tanaka M, Yokohata K, Konomi H, Yamaguchi K, Chijiiwa K, Ohta M: Segmental balloon cytology for preoperative localization of in situ pancreatic cancer. Gastrointest Endosc 1997;46:447-449.

51 Yamaguchi K, Nakamura K, Yokohata K, Shimizu S, Chijiiwa K, Tanaka M: Pancreatic cyst as a sentinel of in situ carcinoma of the pan- creas. Report of two cases. Int J Pancreatol 1997;22:227-231.

52 Yamaguchi K, Ohuchida J, Ohtsuka T, Nakano K, Tanaka M: Intraductal papillary-mucinous tumor of the pancreas concomitant with ductal carcinoma of the pancreas. Pancreatology 2002;2:484-490.

53 Kuroki T, Tajima Y, Tsuneoka N, Adachi T, Kanematsu T: Combined pancreatic resection and pancreatic duct-navigation surgery for multiple lesions of the pancreas: intraductal papillary mucinous neoplasm of the pancreas concomitant with ductal carcinoma of the pancreas. Hepatogastroenterology 2008; $55: 1830-1833$

54 Jarry J, Belleannee G, Rault A, Sa Cunha A, Collet D: Can an intraductal papillary mucinous tumor be a potential indicator of concurrent adenocarcinoma of the pancreas? JOP 2010;11:55-57.

55 Tada M, Kawabe T, Arizumi M, Togawa O, Matsubara S, Yamamoto N, Nakai Y, Sasahira N, Hirano K, Tsujino T, Tateishi K, Isayama $\mathrm{H}$, Toda $\mathrm{N}$, Yoshida $\mathrm{H}$, Omata $\mathrm{M}$ : Pancreatic cancer in patients with pancreatic cystic lesions: a prospective study in $197 \mathrm{pa}$ tients. Clin Gastroenterol Hepatol 2006;4: 1265-1270.

56 Uehara H, Nakaizumi A, Ishikawa O, Iishi $\mathrm{H}$, Tatsumi K, Takakura R, Ishida T, Takano Y, Tanaka S, Takenaka A: Development of ductal carcinoma of the pancreas during followup of branch duct intraductal papillary mucinous neoplasm of the pancreas. Gut 2008;57: 1561-1565.

57 Ingkakul T, Sadakari Y, Ienaga J, Satoh N, Takahata S, Tanaka M: Predictors of the presence of concomitant invasive ductal carcinoma in intraductal papillary mucinous neoplasm of the pancreas. Ann Surg 2010;251:70-75.

58 Tanno S, Nakano Y, Koizumi K, Sugiyama Y, Nakamura K, Sasajima J, Nishikawa T, Mizukami Y, Yanagawa N, Fujii T, Okumura T, Obara T, Kohgo Y: Pancreatic ductal adenocarcinomas in long-term follow-up patients with branch duct intraductal papillary mucinous neoplasms. Pancreas 2010;39:36-40.

59 Tanno S, Nakano Y, Sugiyama Y, Nakamura K, Sasajima J, Koizumi K, Yamazaki M, Nishikawa T, Mizukami Y, Yanagawa N, Fujii T, Obara T, Okumura T, Kohgo Y: Incidence of synchronous and metachronous pancreatic carcinoma in 168 patients with branch duct intraductal papillary mucinous neoplasm. Pancreatology 2010;10:173-178.

60 Ikeuchi N, Itoi T, Sofuni A, Itokawa F, Tsuchiya T, Kurihara T, Ishii K, Tsuji S, Umeda J, Moriyasu F, Tsuchida A, Kasuya K: Prognosis of cancer with branch duct type IPMN of the pancreas. World J Gastroenterol 2010;16: 1890-1895.

61 Kanno A, Satoh K, Hirota M, Hamada S, Umino J, Itoh $\mathrm{H}$, Masamune A, Asakura T, Shimosegawa T: Prediction of invasive carcinoma in branch type intraductal papillary mucinous neoplasms of the pancreas. J Gastroenterol 2010;45:952-959. 
62 Maguchi H, Tanno S, Mizuno N, Hanada K, Kobayashi G, Hatori T, Sadakari Y, Yamaguchi T, Tobita K, Doi R, Yanagisawa A, Tanaka M: Natural history of branch duct intraductal papillary mucinous neoplasms of the pancreas: a multicenter study in Japan. Pancreas 2011;40:364-370.

63 Tanaka M: Controversies in the management of pancreatic IPMN. Nat Rev Gastroenterol Hepatol 2011;8:56-60.

64 Kobayashi G, Fujita N, Maguchi H, Tanno S, Mizuno N, Hanada K, Hatori T, Sadakari Y, Yamaguchi T, Tobita K, Doi R, Yanagisawa A, Tanaka M; Working Group for the Natural History of IPMN of the Japan Pancreas Society: Natural history of branch duct intraductal papillary mucinous neoplasm with mural nodules: a Japan Pancreas Society multicenter study. Pancreas 2014;43:532-538.

-65 Tamura K, Ohtsuka T, Ideno N, Aso T, Kono H, Nagayoshi Y, Shindo K, Ushijima Y, Ueda J, Takahata S, Ito T, Oda Y, Mizumoto K, Tanaka M: Unresectable pancreatic ductal adenocarcinoma in the remnant pancreas diagnosed during every-6-month surveillance after resection of branch duct intraductal papillary mucinous neoplasm: a case report. JOP 2013;14:450-453.

66 Kamata K, Kitano M, Kudo M, Sakamoto H, Kadosaka K, Miyata T, Imai H, Maekawa K, Chikugo T, Kumano M, Hyodo T, Murakami T, Chiba Y, Takeyama Y: Value of EUS in early detection of pancreatic ductal adenocarcinomas in patients with intraductal papillary mucinous neoplasms. Endoscopy 2014;46:22-29.
67 Ideno N, Ohtsuka T, Kono H, Fujiwara K, Oda Y, Aishima S, Ito T, Ishigami K, Tokunaga S, Ohuchida K, Takahata S, Nakamura M, Mizumoto K, Tanaka M: Intraductal papillary mucinous neoplasms of the pancreas with distinct pancreatic ductal adenocarcinomas are frequently of gastric subtype. Ann Surg 2013;258:141-151.

68 Ohtsuka T, Kono H, Tanabe R, Nagayoshi Y, Mori Y, Sadakari Y, Takahata S, Oda Y, Aishima S, Igarashi $\mathrm{H}$, Ito $\mathrm{T}$, Ishigami $\mathrm{K}$, Nakamura M, Mizumoto K, Tanaka M: Follow-up study after resection of intraductal papillary mucinous neoplasm of the pancreas; special references to the multifocal lesions and development of ductal carcinoma in the remnant pancreas. Am J Surg 2012;204:44-48.

69 Ohtsuka T, Ideno N, Aso T, Nagayoshi Y, Kono H, Mori Y, Takahata S, Oda Y, Aishima $\mathrm{S}$, Igarashi $\mathrm{H}$, Ito $\mathrm{T}$, Ishigami $\mathrm{K}$, Nakamura $\mathrm{M}$, Mizumoto K, Tanaka M: Role of endoscopic retrograde pancreatography for early detection of pancreatic ductal adenocarcinoma concomitant with intraductal papillary mucinous neoplasm of the pancreas. J Hepatobiliary Pancreat Sci 2013;20:356-361.
70 Mori Y, Ohtsuka T, Tamura K, Ideno N, Aso T, Kono H, Nagayoshi Y, Ueda J, Takahata S, Aishima S, Ookubo F, Oda Y, Tanaka M: Intraoperative irrigation cytology of the remnant pancreas to detect remnant distinct pancreatic ductal adenocarcinoma in patients with intraductal papillary mucinous neoplasm undergoing partial pancreatectomy. Surgery 2014;155:67-73.

71 Iglesias-Garcia J, Lariño-Noia J, Dominguez-Muñoz JE: Early diagnosis of pancreatic cancer, time to screen high-risk individuals? Minerva Gastroenterol Dietol 2011;57: 205-212.

72 Bartsch DK, Dietzel K, Bargello M, Matthaei E, Kloeppel G, Esposito I, Heverhagen JT, Gress TM, Slater EP, Langer P: Multiple small 'imaging' branch-duct type intraductal papillary mucinous neoplasms (IPMNs) in familial pancreatic cancer: indicator for concomitant high grade pancreatic intraepithelial neoplasia? Fam Cancer 2013;12:89-96.

73 Shi C, Klein AP, Goggins M, Maitra A, Canto M, Ali S, Schulick R, Palmisano E, Hruban $\mathrm{RH}$ : Increased prevalence of precursor lesions in familial pancreatic cancer patients. Clin Cancer Res 2009;15:7737-7743.

-74 Poley JW, Kluijt I, Gouma DJ, Harinck F, Wagner A, Aalfs C, van Eijck $\mathrm{CH}$, Cats A, Kuipers EJ, Nio Y, Fockens P, Bruno MJ: The yield of first-time endoscopic ultrasonography in screening individuals at a high risk of developing pancreatic cancer. Am J Gastroenterol 2009;104:2175-2181. 